\title{
Modern Built Heritage Conservation Policies: How to Keep Authenticity and Emotion in the Age of Digital Culture
}

\author{
Ana Tostões \\ Instituto Superior Técnico, Universidade de Lisboa, Lisbon, Portugal \\ Email: docomomo@tecnico.ulisboa.pt
}

\begin{abstract}
The Modern Movement has demonstrated its long-term legitimacy as a lasting concept endowed with longevity. Relating technology, spatial form and social commitment to one another, through an optimistic faith in progress, modern architects sought to attain new heights of functionality and flexibility in use. The current challenge is to find ways to deal with the conservation of this recent legacy in the continuously changing context of current times, including physical, economic, functional, and fast-moving socio-cultural and political values. To address these questions, 'Modern built heritage conservation policies' explores the restoration and renovation processes undertaken in some paradigmatic case studies: the Tugendhat House (Mies van der Rohe and Lilly Reich, Brno, Czech Republic, 1929-1930), the Crown Hall (Mies van der Rohe, Chicago, USA, 1950-1956), the National Museum of Western Art (Le Corbusier, Tokyo, Japan, 1959) and the Gulbenkian Foundation (Alberto Pessoa, Pedro Cid e Ruy d'Athouguia, Lisbon, Portugal, 1959-1969).
\end{abstract}

KEYWORDS restoration, renovation, conservation, Modern Movement architecture, authenticity, materiality, adaptive reuse

Received June 7, 2018; accepted June 15, 2018.

\section{Restoration and Renovation in the Digital Era}

In the 1960s, Cesare Brandi (2005) stated that 'restoration is the methodological moment in which the work of art is recognised as a physical object with both aesthetic and historical value, with a view to its transmission to the future.' When one approaches the built heritage, the limited function of an art work is obviously enlarged by the social realm of architecture, its purpose and use. The dichotomy of 'art and technique', which stands for the reason and sense of the architectural design discipline is, in a way, enhanced. In fact, the restoration process implies using appropriate techniques to renew the built heritage as much as it means maintaining the artistic value of the work and, therefore, in this respect, the need to retain the character of the building fabric and its authenticity.

The acknowledgment of a $20^{\text {th }}$-century built heritage and the identification of young monuments worldwide confirms this idea. DOCOMOMO-International Committee for Documentation and Conservation of Buildings, Sites and Neighbourhoods of the Modern Movement-is the worldwide organisation caring for the protection of $20^{\text {th }}$-century architecture ${ }^{1}$.

The restoration and renovation of this modern heritage poses constructive questions regarding materiality and physical obsolescence, but also conceptual matters that relate to the character of buildings. According to António Damásio (2009), joy or sorrow can emerge only after the brain registers physical changes in the body: feelings are what arise as the brain interprets emotions, which are themselves purely physical signals of the body reacting to external stimuli. He argues that our internal, emotional regulatory processes not only preserve our lives but actually shape our greatest cultural accomplishments. Emotions are more or less the complex reactions the body has to certain stimuli. Feelings are formed by emotions, and our brain feels emotion. The question is how to maintain the intensity and emotion that great architecture causes when it is necessary to intervene in its materiality to renew and adapt it to the current situation.

This essay addresses some of Brandi's unanimously recognised contributions to architectural conservation 
theory and proposes their application to the architectural heritage of the Modern Movement on the basis of authenticity, one of the most operative concepts. Recognising the incisive categorisation proposed by Alois Riegl (1982) of artistic and historical-values, age-value, use-value, or newness-value, and considering the recent-past status of the heritage of the Modern Movement, it is fair to say that artistic originality (creativity) and age (antiquarianism) have been the dominant qualitative values that have defined most art and architecture in a Western context since at least the $18^{\text {th }}$ century; however, as we have come to discover in recent years, such values are not, and never have been, universal.

The fundamental principles of what we today call conservation were the central ideas that Ruskin (1860) expressed in The Seven Lamps of Architecture. The built production of the $20^{\text {th }}$ century, particularly after 1945 , is seen today as a matter of disciplinary practice and conceptual reflection for the contemporary architect. In fact, an architectural project intervening in an existing structure is defined as a safeguard project, either as a conservation project or a new materiality. It is a demanding task: conservation, repair, consolidation, restoration, adaptation and extension. It is underpinned by the material history of contemporary built production and demands a complete knowledge of materials, construction sites, and construction systems. Following the methodology proposed by Franz Graf (2012), it is important to consider two fundamental interconnected themes. The first of these comprises the materials, constructive techniques, and innovations, by which the object itself was built, working as the first document, and its architecture and history for which new ways of reading are proposed. The second contains the specificities of the safeguard project and the questions prompted by it; the materiality, impregnated with history and theory, that must be articulated with the project transforming it. Analysis and diagnosis reveal its potential, generating not only responses, but also a series of possibilities and strategies for intervention predicated on patrimonial, economic, energy and normative values.

Assuming that we are no longer living in the machine age and that we are going through a revolution leading to a digital age, we must consider safeguarding this recent past in two directions at the same time: the cultural and the constructive project (Banham 1960). Reconsidering material history and its relation to the safeguard project implies approaching its construction and history from the different viewpoints of the researcher, the architect, and the professor of theory and design. The history of building the architecture of the Modern Movement as a discipline is still in its early days. If monumental restoration was based on solid historical foundations drawn from the writings and works of the founding $19^{\text {th }}$-century thinkers, Ruskin, Viollet-le-Duc, Boito, or Riegl, safeguarding $20^{\text {th }}$ century architecture is a recent concern. There is some literature on the restoration of the modern, as a result of considerations based on historical monumental restoration, but no specific work that establishes the pertinence of safeguarding this recent past as a cultural and constructive project, while drawing on history, techniques and critical speculation.

In order to contribute to this knowledge, this paper analyses intervention projects carried out on existing and paradigmatic works on two continents by renowned western architects of the $20^{\text {th }}$ century, from Switzerland, Germany and Portugal. These are Le Corbusier (1887-1965), Mies van der Rohe (1886-1969), and a team of three Portuguese architects, Pedro Cid (1925-1983), Alberto Pessoa (1919-1985) and Ruy Athouguia (1917-2006) who worked together with the active collaboration of landscape architects. These interventions demonstrate global influences and represent a re-creation of modern principles interpreted in broad terms, without rhetoric, and with considerable imagination.

These four cases reveal, in different ways, a search for truth in their interventions, not only to restore the original, but also to improve it. Two of the works are recognised as World Heritage by UNESCO. They represent different programmes, ranging from iconic housing from the heroic period of the Modern Movement in the 1930s, to teaching and cultural facilities, and include a museum built during the mature period of post-WWII modernity.

The Tugendhat House and the Crown Hall are two different works, in terms of programme and period, by Mies van der Rohe, where we can testify to their spatial clarity, constructive rigor, indoor-outdoor relationship, transparency, grandiosity and spatial flexibility; they represent the total artwork. In Le Corbusier's National Museum of Western Art we can find the grand gesture, the revival of the Museum of Unlimited Growth, the modern envisaged as a planetary laboratory, the repeatable and the exception, Japanese pride supporting the path to recognition as World Heritage. The Calouste Gulbenkian Foundation (FCG) is a work that reflects the influences of Mies and Le Corbusier and anticipates the formulations of Louis Kahn, through an attention to detail that guarantees its authenticity, in the transparency achieved where the interior-exterior relationship is key to its emotional effect, in the spatial continuum 
determining the character of the building, and in the sobriety and restraint of the choice of materials.

The debate on intervening in modern heritage does not raise questions which are structurally different from those related to so-called 'historic' heritage issues. Especially because, when we talk about heritage, it is a universal discourse with specific typological, constructive and linguistic characteristics from each age (Tostões and Liu 2014). However, conceptual, formal and programmatic characteristics specific to modern built heritage require 'custom designed' intervention criteria to be established. Awareness of the architectural heritage of the Modern Movement is recent, and debate is urgently required on its evaluation, the direction of its conservation and its reuse. Although so-called 'historic' heritage is subject to special laws and regulations that take into account its characteristics, the heritage of the $20^{\text {th }}$ century-and especially those buildings that have not (yet) found a place in the history of architecture-are still considered, with respect to regulatory compliancy, on the same level as new construction. However, recent heritage also has characteristics that require specific treatment.

First of all, modern heritage represents a huge built volume. The preservation of the significant buildings and sites of the Modern Movement as an artistic expression, poses a substantial physical and economic problem. One of the main tasks of architects today is the reuse of existing buildings, most of which are of recent construction, making the phrase 'building in the existing' commonplace nowadays (Tostões and Ferreira 2016).

Secondly the massive built volume of the $20^{\text {th }}$ century confronts us with objects that are still largely retained in the limbo of history and architecture criticism. As noted by Bruno Reichlin (2001), 'the emerging confrontation with the recent, with that which has not been judged, with the anonymity of what is trivial, becomes a problem.' On the one hand, architectural historians who deal with the past century are still developing critical tools to understand what place some of these recent works have in the history of architecture. On the other, it is difficult to defend some examples of architecture of the $20^{\text {th }}$ century with respect to the public at large. The appreciation of this heritage is still in progress: it is a complex task which today is going through a very delicate phase, because we risk losing valuable examples of recent architecture if recognition is not given in time. Hence the need to be very careful.

In third place, the Modern Movement is often incorrectly and superficially considered a style, a simple formalism, although many modern architects fought against this idea. Walter Gropius $(1955,3)$, in The Scope of Total Architecture, defined modern architecture as a method: 'My intention is not to introduce a Modern Style ... but to introduce a method or approach that helps address a problem in terms of its particular conditions.' The German architect clearly contemplated Modern Movement architecture as a process rather than a style.

Fourth and lastly, the heritage of the $20^{\text {th }}$ century is technically fragile, because its innovative technologies were not based on long-standing constructional tradition. Faced with the challenge to build homes, work spaces and facilities for a large number of people with a limited budget, the architects of the Modern Movement developed several experimental and cheap construction technologies. Their willingness to experiment, combined with a certain degree of professional naivety and a desire to achieve a minimalist aesthetic by using new technologies, was also a source of technical imperfections in most of the early experiments. However, modern architects also showed a great interest in issues related to the pursuit of efficiency and economy, including the efficient use of materials and a conceptual approach to economy of resources. Some of them tried to solve technical problems of building performance, which are very close to the themes of today's literature on 'sustainable development'. The buildings of the Modern Movement also often had a rapid functional obsolescence because they were designed to perform very specific functions. It is sometimes difficult to find a new practical use for these constructions. The idea that buildings have a functional life of limited duration is not new, and it is something that appeared early in the literature related to the preservation of modern heritage ${ }^{2}$. This perceived obsolescence stimulates ex novo construction. The focus is increasingly on efficiency and performance, so the intrinsic value of the original building, both inside and outside, is often excluded. But this approach is in clear contradiction with the concept of 'sustainable development'.

\section{Modern and Sustainable ${ }^{3}$}

Modern Movement architecture changed practice and theory in ways that were consistent with an industrial age. It is a product of industry and engineering as it followed the spread of scientific management: historically acknowledged to be the most controversial and influential approach to the organisation of work. Modern Movement architecture meant contemporary technology, form, expression, and above all, the belief in the architect's social mission towards creating a new and better world. Architecture arose as a social condenser (Le Corbusier's 
'architecture or revolution?') along with the democratisation of life. Even its espousal of the reuse of materials and technologies, spatial and functional transformations, and regulatory reform, now seem to be part of the contemporary agenda. The Modern Movement always strove for efficiency and economy, i.e., an efficient use of materials, a design approach that incorporates the intelligent saving of resources. This concept is nowadays synthesised into socalled sustainability, whose misuse sometimes leads to the trivialisation of the word.

The creation of efficient devices according to place and climate, the thinking on building physics, the relationship between heritage, energy and economy, are themes for discussion both as Modern Movement concepts, on a documentation level, and with respect to interventions in Modern Movement buildings nowadays, on a conservation level. The aim of this discussion is to relate heritage, economic constraints and energy issues, within a global strategy for the future. As Carl Stein states in his Green Modernism, although the CIAM grid was incredibly ambitious in its attempt to bring all of the issues affecting planning and design into a single matrix, what is perhaps most relevant was the use of what would now be called multi-media notation within each of the matrix cells. By accommodating text, drawings and maps, photographs and other notations, the grid supported the inclusion for evaluation of factors that went far beyond simple quantitative measurement. It specifically acknowledged the importance of issues dealing with life, the spirit and intellectual happiness.

The accomplishment of sustainability poses a fundamental dilemma: materiality and permanence. Permanence and thus the durability of buildings and building construction is not always encountered in these modern structures, where functional specificity and experimentation with materials were seen as integral to their concepts. This has led to arguments that these structures are fundamentally temporal and were not intended to remain. This is, in many instances, a gross simplification and the very fact that they still stand would seem to indicate their relative durability. The other issue that is often raised in the discussion about preserving modern architecture concerns the idea of functional obsolescence. In other words, buildings that are tailor-made for particular functions, easily and quickly become operationally, technically and economically redundant when those functions change. This is the case, for instance, of the first cinemas built to respond to a new and modern social programme, that nowadays have lost their function or living sense as a 'monument of modern life, as a key building of contemporary urban life.
By being, in turn, tied to return on investment, permanence and durability, they are not necessarily supported beyond their investment period unless the building can be recycled, which requires reinvestment (Prudon 2008, 2010). It is there that, by comparing the existing structure with a new building, the argument is often made that a new building would be more efficient and sustainable. Similarly, by over-emphasising operational and performance efficiencies for the interior and the exterior, the intrinsic value of the original fabric is frequently overlooked. Carl Stein $(2010,81)$ argues that the pioneers of the Modern Movement provided us with all the tools and design processes for resolving sustainability issues: 'While Modernism does not, in itself, offer new design tools for building reuse and historic preservation, it does provide a very clear framework for the appropriate application of these tools.' In many ways, Modern Movement architects anticipated and sought to scientifically address the problems of building performance, which are so prominently discussed in today's literature (Tomlow and Wedebrum 2006). Because so many of these proponents worked in northern Europe, the emphasis was on heating and thus insulation. For instance, the Swiss Federal policy document titled Recommendations on Improving Energy Consumption in Historic Monuments states that: 'heritage and energy are both legitimate issues; they share essentially the same concerns and seek the same outcomes: supporting sustainable development by preserving non-replaceable natural and cultural resources' (Graf and Marino 2011).

\section{Authenticity and Gesamtkunstwerk: Mies' Masterpieces between Europe and United States ${ }^{4}$}

Through a combination of a precise design, good construction, advanced technologies and outstanding materials, Mies van der Rohe, together with Lilly Reich, satisfied the Tugendhat family's wish for innovation, originality and truth ${ }^{5}$, creating an exceptional modern way of life based on an open plan. The Brno house (1928-1929) consists of a unique global work of art-Gesamtkunstwerk -in terms of its placement in its natural setting, its spatial organisation, construction, technical equipment and interior furnishings ${ }^{6}$. In 2001, the Tugendhat House was recognised as World Heritage by UNESCO as 'an outstanding example of the international style in the Modern Movement of architecture as it developed in Europe in the 1920s, under the condition of conducting extensive restoration (UNESCO 2018) (Figure 1).

The aim of the restoration project, in accordance with the requirements of monument conservation, was the 


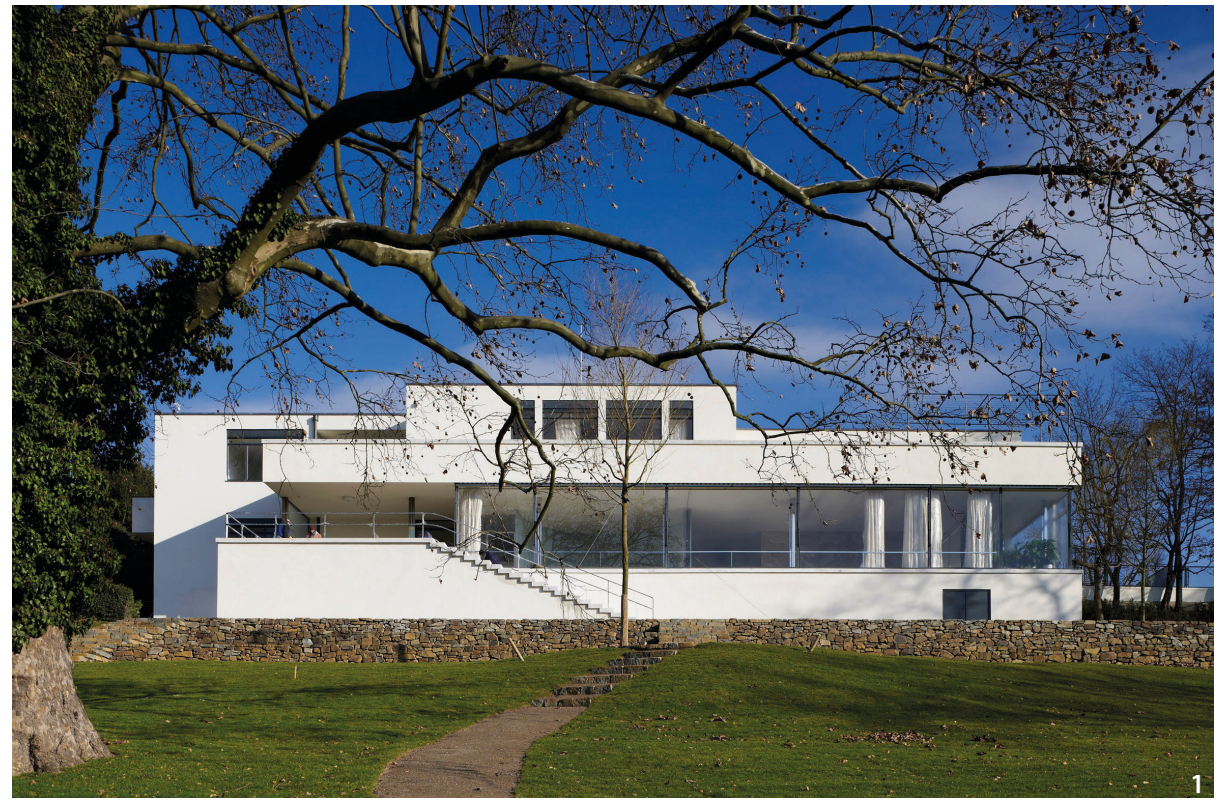

Figure 1 Mies van der Rohe and Lilly Reich, Tugendhat House, Brno, Czech Republic, 1929-1930. Garden façade, after restoration (Source: Alex Dill). prolonging of the lifetime of the monument in an original state and the reconstruction of missing original parts.

To that end, a long and careful conservation-science study was carried out': 'An important precondition to preserving the cultural values of a historic object is the investigation and documentation of materials and surfaces by conservators/restorers. ... The entire process of conservation studies and the associated interdisciplinary historical, technical and scientific investigations is known today as conservation-science investigation.' (Hammer 2014, 164)

The decisive criterion in restoring the building was its place in the history of architecture, understood as a work of art of universal importance. Therefore, the interdisciplinary cooperation between architects, structural engineers, art historians, conservator-restorers ${ }^{8}$, material scientists, chemists, physicists, and building climate control engineers, was fundamental. The building was extensively studied through a transdisciplinary process including all appropriate historical, scientific, technological and empirical methods. All the layers of materials (plasters, stone, wood, wall, metal), techniques, surface materials and colours covering all the historical phases, were documented and researched. The damaged and the well-preserved components were registered and analysed. Damaging factors were identified. Methods for conservation and restoration, as well as the skills required for repair and maintenance, were developed. It was understood that built heritage was also important as a source of knowledge of technical solutions (Hammer 2014, 165).

The project for the rehabilitation and restoration occurred between 2010 and 2012 ${ }^{9}$. To advise the City of Brno on the implementation of the restoration of the Tugendhat House according to the principles of the preservation of a monument, an International Expert Advisory Commission (THICOM ${ }^{10}$ was established that actively accompanied the process. The restoration process was based on the belief that 'heritage conservation as a societal practice only makes sense ... if the material authenticity is preserved (Hammer 2014, 165).

In the face of this conceptual context and the importance of ensuring the original materiality, this restoration was intended to be as close to the original as possible, when necessary, by reinstating original materials, with the intent of preserving the authenticity of the original structural materials. Beyond the physical aspects of the restoration, some structural problems were also solved, while the spaces and the lighting quality have been carefully restored. The house has been discreetly adapted to serve as a museum, accommodating many visitors, requiring control systems for temperature, security and fire detection. The toilets were installed in the basement, which also houses an exhibition of original photographs and a bookshop. Legislation was applied with common sense regarding safety and comfort regulations without prejudicing the spatial and constructional value of the building details. The fundamental structural issues that the Tugendhat House faced before the renovation and restoration process involved the drainage system, the deformation of the garden terrace, the waterproofing of roofs and the corrosion of steel structures.

The original plaster of the exterior terrace walls was detached by a conservator-restorer and re-attached to the 


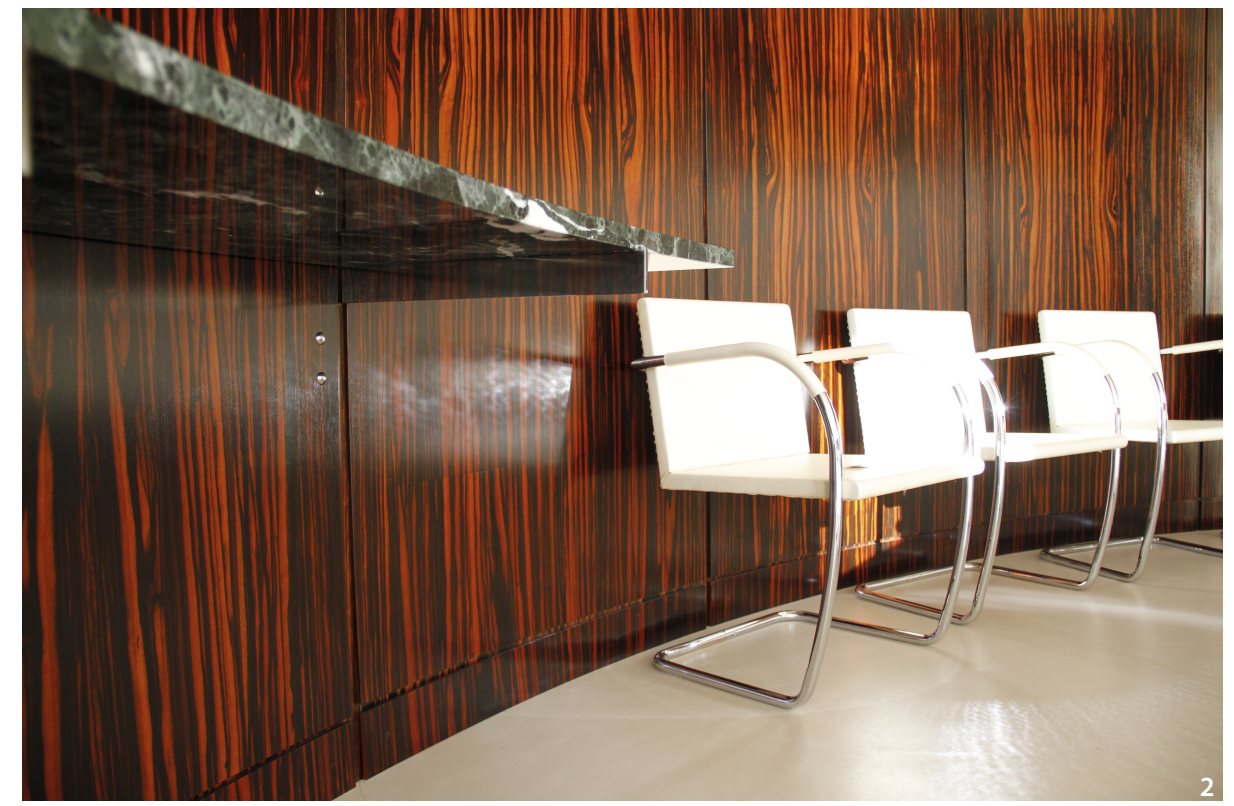

Figure 2 Mies van der Rohe and Lilly Reich, Tugendhat House, Brno, Czech Republic, 1929-1930. Main living room, dining area, the curved inner wall made of Macassar ebony, after restoration (Source: the author). brick wall rebuilt in the correct original place, and the pavement of the floor and stairs, made of Slovakian travertine introduced in the 1980s renovation, was replaced with the original Italian Tivoli travertine. Both, the garden terrace and the upper terrace received a new waterproofing system. After the removal of insulation layers introduced in the 1980s and the lowering of the parapet to its original height, a new roof covering was developed using contemporary materials and technology: cellular-glass roof insulation, modified-bitumen sheet, and POCB membrane; the roof parapet was covered by an adhesive bitumen on the underside and the rainwater gutter outlets and downpipes were clad with pre-weathered titanium zinc.

The restoration of all the structural steel components and metal fittings was of crucial importance. The original technology of oil-based paints was applied to all metal cladding, as in the original.

Furthermore, almost all the technical artefacts and building services engineering components were restored to full working order: the whole ventilation system, including humidifier, cooler, fan, and filter for oil and wood shavings with mechanical controls, has been preserved in its original state and is fully functional; the heating unit was reconstructed as a technical monument; the engine room for the retractable windows and the boiler room was restored with great attention to detail, as were the tubular heating elements, the rainwater tank and the ventilation equipment.

All the plaster was preserved in its entirety after removal of secondary coatings from the surfaces. The original exterior plaster was smoothed traditionally with a wooden board and consequently had a sandy texture. The original thin layer of slaked-lime whitewash pigmented with fine grains of Bratčice sand barely covered the roughness of the surface thus producing the somewhat impressionistic polychrome effect of its original yellowish exterior tone. The conservators treated the wall surface to restore the gypsum degraded by pollution. The actual final coating of the façade followed the traditional technique used in the original finish: a wash of slaked lime pigmented with sand. Friable layers were injected and reinforced. Because of its poor state of conservation, the original stucco lustro of the interior wall was newly coated with a thin layer using nearly identical materials: limestone and marble dust, with some linseed oil and cellulose-ether as the binding medium. Again, as with the façade coating, it was pigmented with fine silt size grains of Bratčice sand and was finely sanded creating the illusion of a polished marble surface (Figure 2).

Good luck played its role in the restoration process too: the original bathtub, missing since the 1940s, was found in a nearby house; a part of the original Macassar panels was found in the former headquarters of the Gestapo at the University of Law in Brno in 2011. Through the analysis of old photographs, the restorers were able to reinstate the authentic material to its original position and restored the inner face to its original state. Partially missing parts were covered with new Macassar veneer. Original white and black RAKO Czechoslovakia ceramic floor tiles were discovered during the construction work, under later-added layers. Also, while removing the PVC flooring that had replaced the original DLW (Deutsche Linoleum Werke) linoleum during the 1980s renovation, an authentic floor 


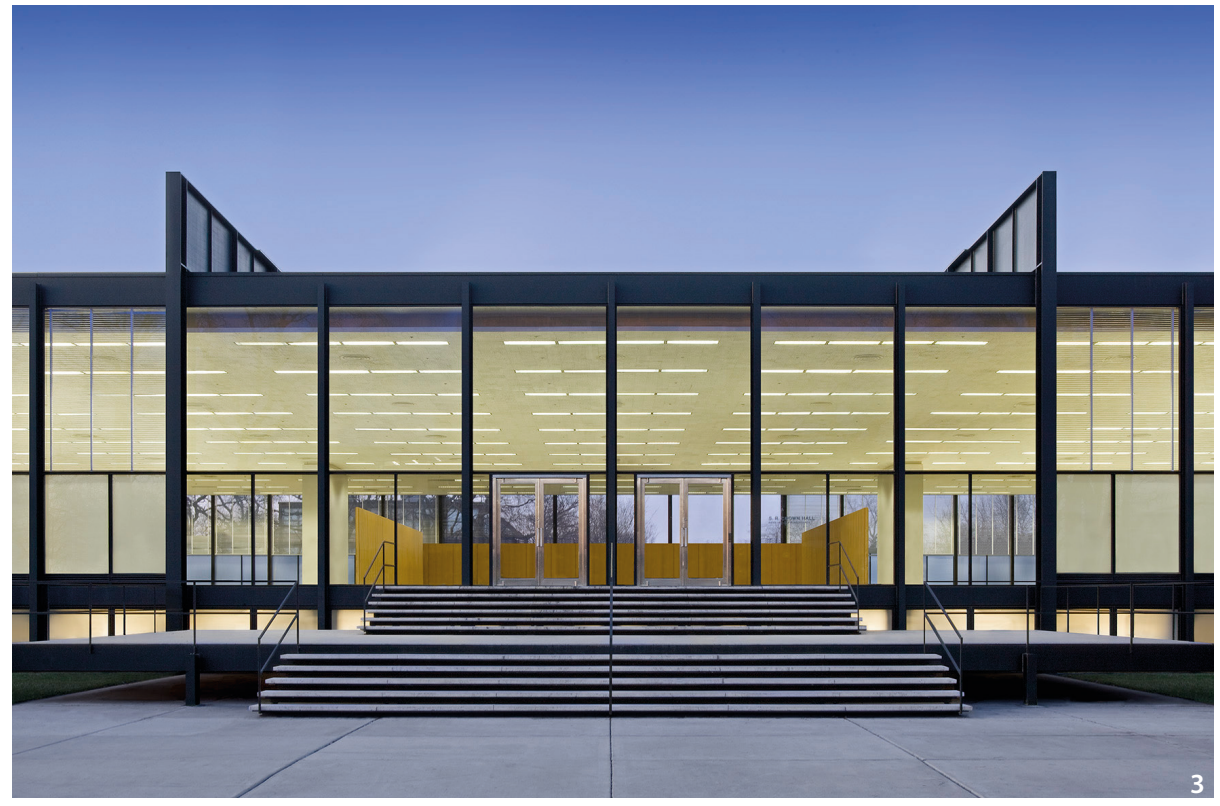

Figure 3 Mies van der Rohe, Crown Hall, Chicago, USA, 1950-1956. Restoration by Krueck + Sexton Architects (Source: William Zbaren). screed, made with Sorel cement, was discovered. This cement was made from a mixture of magnesium oxide (burnt magnesia) and magnesium chloride with wooden filler materials. After this discover, the experts decided to reproduce this material, to use as the substrate of the linoleum, in accordance with the original formula. Also, the manufacturer DLW, who had supplied the original linoleum for the house in 1930, produced the linoleum.

Within the new functional requirements of the building, inaugurated as a monument of modern architecture, the house's security had to be an important component of the restoration project: fire protection and security was achieved through modern technical equipment with a minimum of visible changes. The search for maintaining its character and materiality was decisive in achieving the outstanding results. As Mies explained to his clients that 'it is important, especially in a modern building which is almost free of decoration and ornament, to use precious materials' ${ }^{11}$ that's why 'materials are not merely carriers of meaning; they also produce meaning. ... Materiality incorporates the historical, artistic and cultural characteristics assigned to the (architectural) monument' (Hammer 2014, 164-165). This unique restoration confirmed the necessity for such conservation-science studies, accompanied by an active international advisory board.

During WWII, in 1940, at the time of Mies van der Rohe's exile in the USA, he was commissioned to develop the master plan for the Illinois Institute of Technology (IIT), in Chicago, occupying 50 ha and containing twenty buildings. It is nowadays the greatest concentration of Mies van der Rohe buildings in the world. The Crown
Hall, completed in 1956, is one of these buildings, and was designed to host the School of Architecture. It was referred to by Mies van der Rohe as 'the clearest structure [I] have done, the best to express [my] philosophy', his 'finest work' (Harboe 2000). In 1997, it was classified as a City of Chicago Landmark, and in 2001, as a National Historic Landmark (Figure 3).

The Crown Hall is a free volume, contained in a rectangular shape by four glass walls on two levels. The vegetation around the building regulates the sunlight on the glass façades, and these promote an open dialogue with the park and the Chicago skyline beyond. Through an innovative technology that combined steel and glass, where the roof hangs from steel trusses instead of being supported above them, the Crown Hall was the first clear-span structure designed by Mies van der Rohe, allowing him to achieve his desire to create a 'universal space'. At the floor level, the translucent glass promotes curiosity, while the clear glass higher up encourages people to contemplate their surroundings: 'the effect is monumental, for it gives the appearance of the building having transubstantiated and elevated to a point where it seems as if the whole is rising from itself' (Nicholson 2018). 'During the day, Crown Hall seems a precisely defined, translucent, and transparent volume in perfect repose. At night it becomes a reliquary of light, as its interior illumination appears to make the building seem almost to float on a cushion of light' (Harrington 1993, 388-389).

After 50 years of intense use, Crown Hall fell into major disrepair: the exposed steel frame was seriously corroded, and the glazing system was cracked. Kruek + 

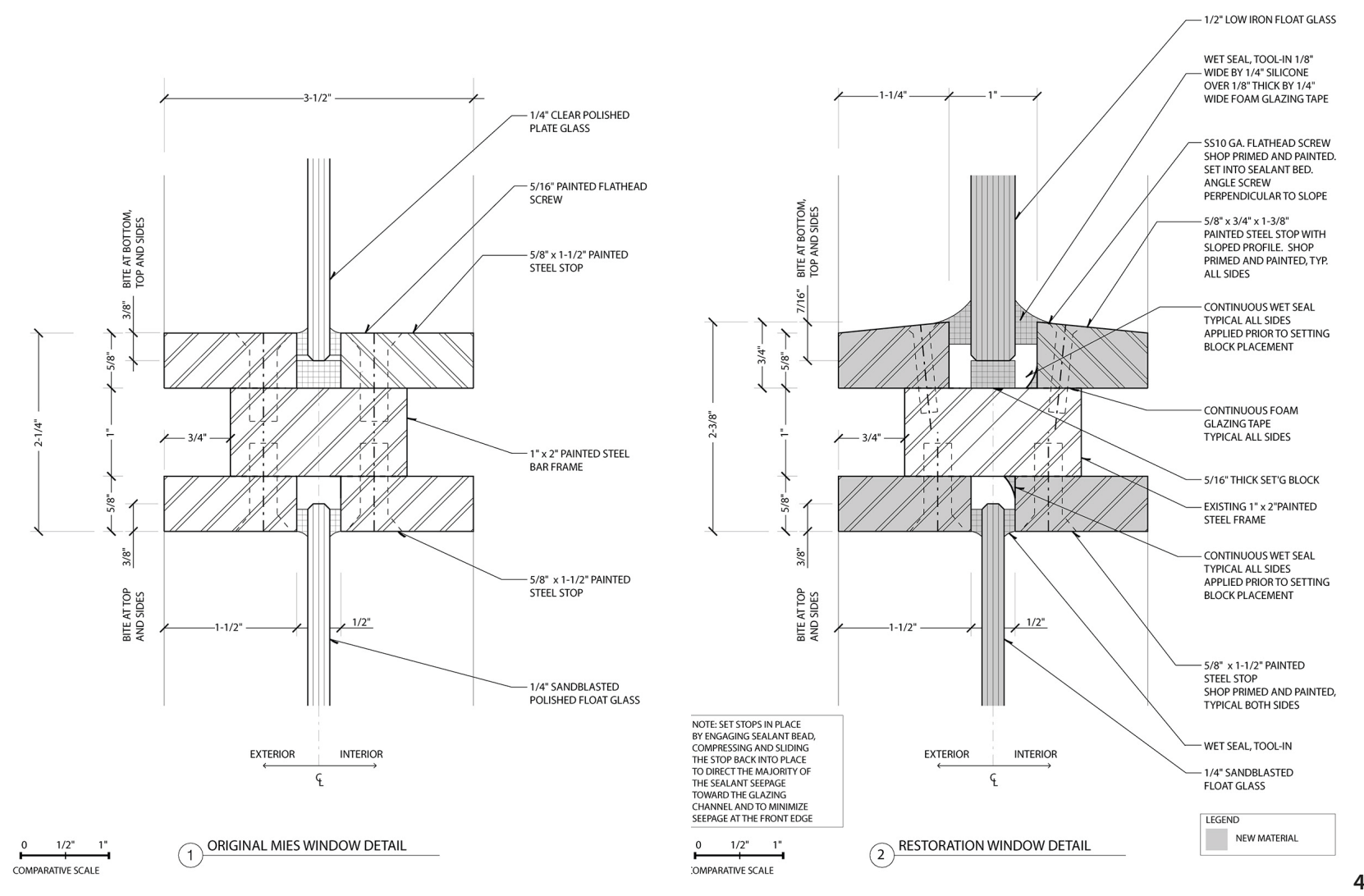

Figure 4 Mies van der Rohe, Crown Hall, Chicago, USA, 1950-1956. Detail drawing of original (left) and restored (right) glazing stop condition (Source: Krueck + Sexton).

Sexton Architects were selected to undertake the renovation project of the building, that has been initiated after a thorough analysis on the causes of the deterioration by an interdisciplinary team including experts from the architecture, engineering, construction, preservation, glazing and sustainability fields. The process was mainly focused on the façade's steel and glass stop details as it was where the steel, glass and paint met, in a critical situation. It was concluded that inappropriate renovations undertaken in the 1970s by SOM, had not only compromised the original architectural integrity and clarity of the building, but had also not ensured the highest standards of historic restoration. Therefore, in parallel with the technical restoration of the Crown Hall, the goal of the project was to restore its original ideas, materiality and functionality, 'allowing the world at large to once again experience one of the most powerful works of modern architecture' (Sexton 2014). To that end, 'since Crown Hall is a superior example of the "less is more" axiom, the attention to material, detail and craftsmanship had to be of the highest order' (Sexton 2014).

The glass and modified aluminium stops installed in the 1970s were then removed and extensive studies for the best strategy to substitute them were undertaken. Six were pre-selected. The exterior steel was restored through the elimination and replacement of the corroded steel and the sandblasting of what remained. The entry doors of the building were sent to their original manufacturer, Ellison Bronze Inc., for renovation and updating with modern hardware and security devices. The entry porches received new Italian travertine selected to match the texture, colour and grain of the original stone.

Based on a careful review of the chemical, moisture, galvanic, electrochemical, thermal expansion and historic preservation issues, steel replacements stops were recommended and implemented for all portions of the glazing system. Kruek + Sexton Architects explained that 'at the upper stops, current codes required increased thickness of the stop at the glazing channel from the original 5/8-inch (16 mm) bar to $3 / 4$ inch $(19 \mathrm{~mm})$ to allow sufficient support of the large upper glass lights' (Sexton 2014). How to accomplish that change, while preserving the character of the curtain wall? After deep analysis and detailed studies, a sloped profile was developed, able to address the support requirement of the glass, improve the curtain wall performance and ensure drainage away 


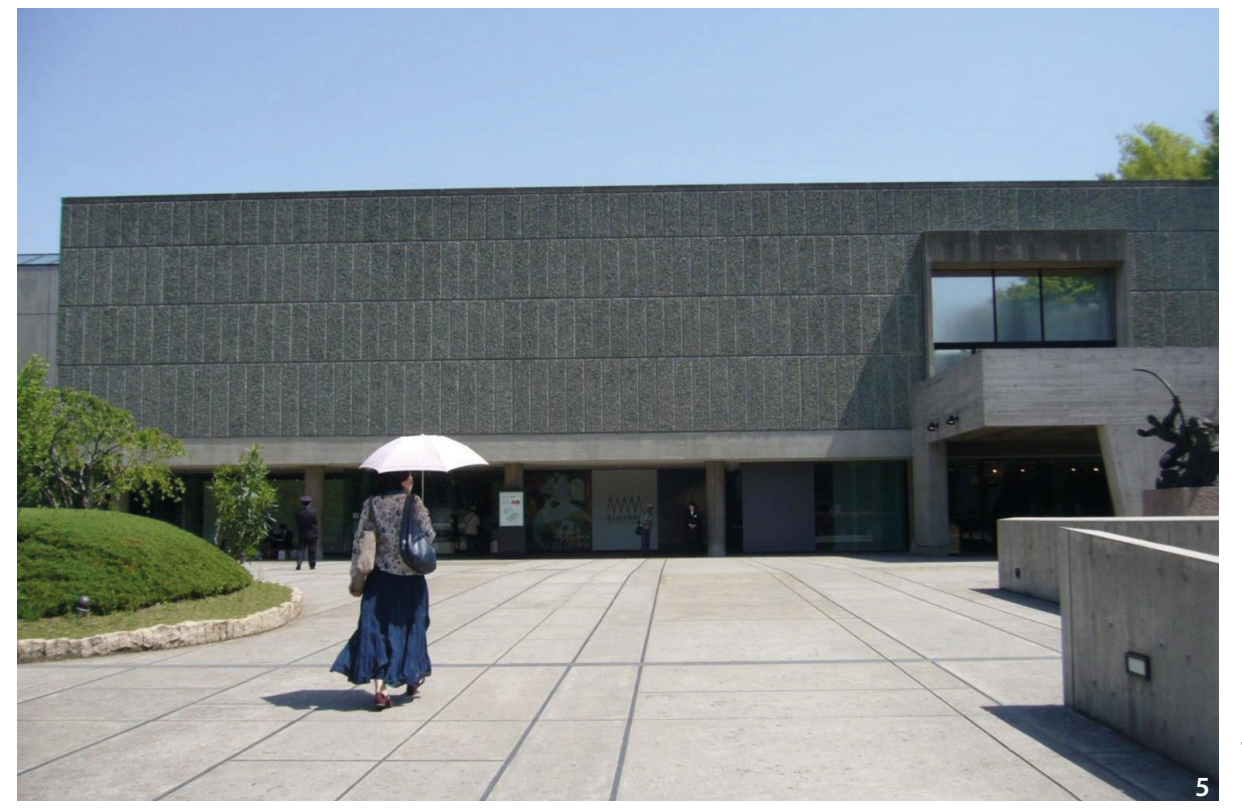

Figure 5 Le Corbusier, the National Museum of Western Art, Uenokoen, Tokyo, Japan, 1959 (Source: the author). from the glazing channel, while maintaining the appearance and proportion of the original. 'Some on the design review committee thought this approach was heresy. How could a sloped piece of steel be installed into arguably one of the most rigorously rectilinear buildings of the $20^{\text {th }}$ century? Our answer was very simple, 'you don't see it."(Sexton, 2014) (Figure 4)

The translucent laminated glass that SOM introduced in the building to solve issues of safety and maintenance when replacing the original sandblasted glass, caused two new problems: an increase in solar energy absorption $(30 \%$ instead of 5\%) and excessive reflectivity. Additionally, glass breakage occurred due to expansion caused by thermal movement and corrosion of the steel.

Beyond correcting all these problems, the replacement of the glass also had to consider the wind load requirements, particularly problematic in the upper lights. The glass to replace the obsolete glazing-translucent in the lower lights-was selected after a comparison of several full-size mock-ups. The selection criteria met contemporary requirements in terms of energy efficiency and technical resistance, and ensured longevity, while also preserved its original character, in which parameters such as fidelity to original colours, textures, reflectivity and translucency, were fundamental. In the end, no one in the team of experts could detect any difference between the selected solution and the original one.

The renovation of the Crown Hall, undertaken by Mark Sexton, is a highly successful project that proves it is possible to restore a modern masterpiece, adapting it to contemporary demands, without losing its historical design, functional character or significance. In the end, the building was able to retain his function as a living lesson in architecture for students.

\section{Adequacy: The Renovation of the National Museum of Western Art in Tokyo ${ }^{12}$}

In Japan, measures against earthquakes including the application of the 'national seismic standards' have been implemented since the 1920s (Okada 2009).

Due to regular advancements in seismology and earthquake engineering, seismic design codes for buildings are continuously under revision; in particular, the level of earthquake resistance required for buildings was significantly increased in Japan in 1981. As a consequence of these changes, the seismic performance of buildings constructed after 1981 has greatly improved, but there were unresolved concerns that some seismically unsafe structures existed amongst those built before that time.

In 1995, the measurement of seismic controls of all structures built before 1981 was quickly adopted, including the enactment of related policies, such as the Law on the Promotion of the Seismic Rehabilitation of Buildings. In such circumstances, an assessment of seismic capacity was conducted on the National Museum of Western Art (NMWA), which was built in $1959^{13}$ in Ueno Park in Tokyo. Despite meeting the seismic design codes of that time, it was considered susceptible to suffering substantial damage in the event of a strong earthquake. Beyond the need to ensure the safety of visitors and the valuable museum collection it held, 


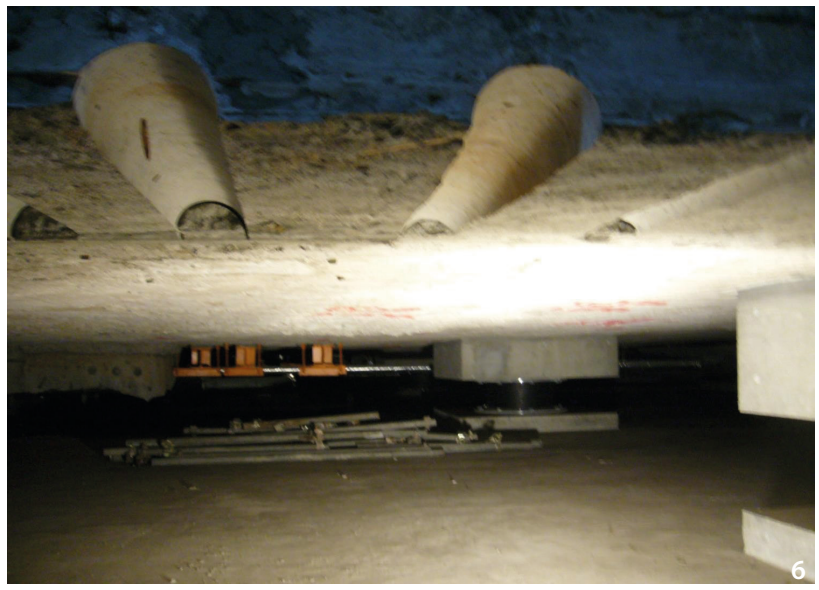

Figure 6 Le Corbusier, the National Museum of Western Art, Uenokoen, Tokyo, Japan, 1959. Seismic Reinforcement, 2008 (Source: the author).

the Museum is recognised as a work of exceptional architectural value by the world-renowned architect Le Corbusier $^{14}$ (Figure 5).

The main building of the NMWA is prized as the sole surviving example of the work of Le Corbusier in Japan, and in recognition of both its historical and architectural value, it was designated as an Important Cultural Property on December 21, 2007. The forecourt garden and adjacent areas of the site reflect Le Corbusier's design theories and the landscape connecting the garden with Ueno Park maintains the scenic beauty of its original conception. Because of this, the museum and site were officially listed as a Registered Monument/Place of Scenic Beauty on July 23, 2009. The main building of the NMWA is a realisation of such elements of Le Corbusier's Five Points of a New Architecture, as the use of pilotis, roof garden, and a free plan. Employing Le Corbusier's signature Modulor approach to proportions throughout its design, the building is also one of only three extant prototypes of the architect's concept for a Museum of Unlimited Growth ${ }^{15}$. For all of these reasons, it has received much international attention and acclaim.

The NMWA's goal was to faithfully preserve the spatial concept of Le Corbusier's Museum of Unlimited Growth, highlighting the architectural beauty of the museum's main building ${ }^{16}$. Therefore, it was absolutely indispensable to take care of the seismic security issue without delay.

With this in mind, the NMWA renovation committee was established in July 1995. Through this committee, the architectural value of the museum was examined, and having determined that, as it is representative of Le Corbusier's museum architecture, and is the sole work of the modern maestro in Japan, it was decided that methods for seismic strengthening should be investigated that would best preserve the original architecture, both on the exterior and interior.

Conventional methods to strengthen this structure involved increasing the resistance of retaining walls while widening the columns and studs in order to improve their seismic response capability. However, although these 'conventional' proposals would have ensured its resistance to earthquakes; it would have had an unfortunate effect on the original structure with visually and spatially detrimental modifications or additions, compromising the character of the building.

In the end, the question came down to whether it would be possible to use a method of seismic base isolation recently developed for new structures, which was only then being tested. This method absorbs ground vibration by installing a system of rubber roller devices that provides seismic base isolation and controls the seismic behaviour of the building above. According to calculations, it would be possible to ensure the seismic safety of the building with little change to the original structure (Figure 6).

But it was still necessary to overcome two problems. The first concerned the construction budget. In comparison with traditional methods this new method involved considerable expense, potentially equivalent to the cost of an entire new building. This cost was justified, from various points of view, by the need to preserve the original building, and a report was prepared for a consensual budget evaluation by the government. The committee then obtained the resources to work on the method of retrofitting the seismic isolation structure.

The other question was whether the work would even be possible. For new structures it was simple, but for an existing building it was not an easy task. It led to a complicated procedure of first raising the building to create a space between the surface and the foundation structure for the installation of the new foundation. After the installation of supporting rubber seismic isolation devices, the existing building then had to be lowered to its previous level. It would be the first time this had been done in Japan.

Despite its complexity, the retrofitting work was completed in March 1998 and can be viewed through an observation window located in the basement. The Japanese pride in this magnificent work strengthened the candidacy of the National Museum of Western Art for UNESCO's World Heritage list, having been added to the list of Masterpieces by Le Corbusier in the world. 


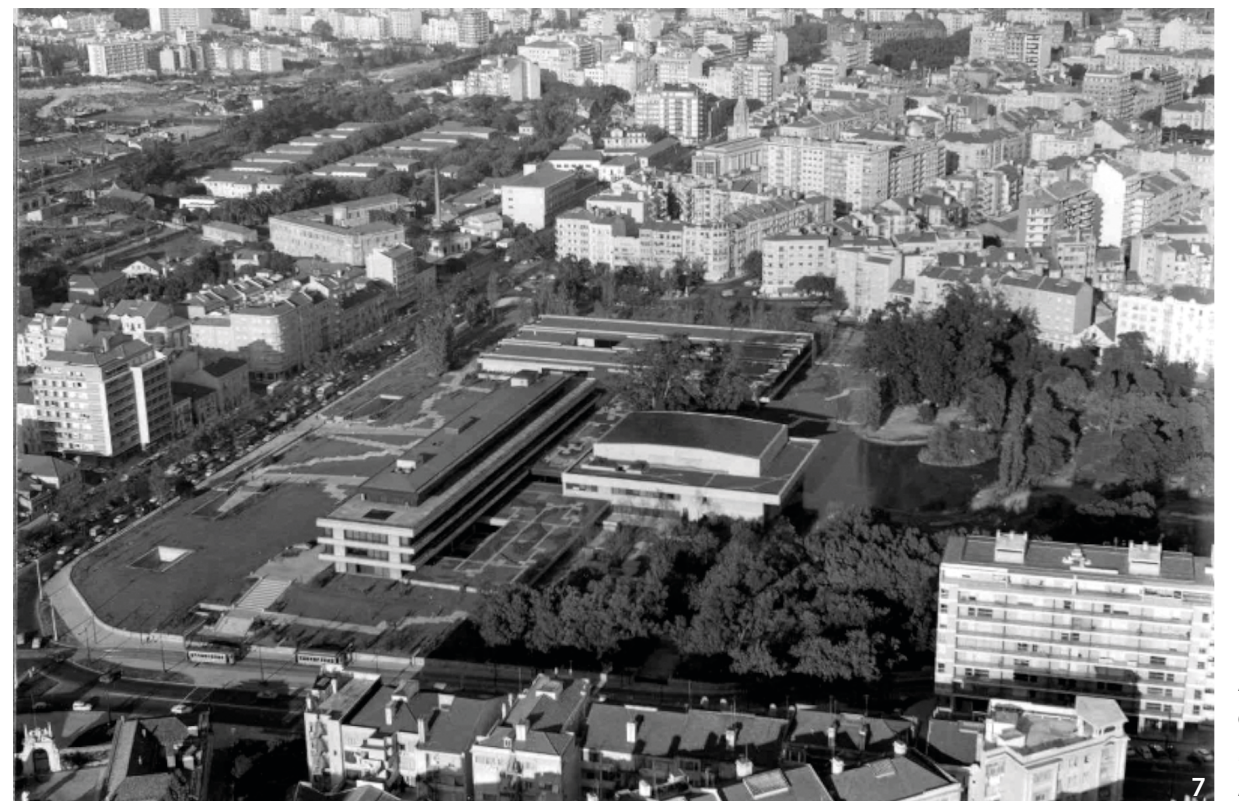

Figure 7 Alberto Pessoa, Pedro Cid, Rui Athouguia, Calouste Gulbenkian Foundation, Lisbon, Portugal, 1969 (Source: Mário de Oliveira, Calouste Gulbenkian Archive).

\section{How to Keep a Monument Alive: The Gulbenkian Foundation Auditorium ${ }^{17}$}

The Calouste Gulbenkian Foundation headquarters and museum complex (1959-1969) had a fundamental role in building science in Portugal and achieved a high level of technical excellence and comfort, whilst beautifully linking its building and garden (Tostões 2015b, 2015c; Tostões and Carapinha 2016). Located in central Lisbon, within a 7.5-hectare park and occupying an area of $25,000 \mathrm{~m}^{2}$, it was designed by the architects Alberto Pessoa (19191985), Pedro Cid (1925-1983) and Ruy Jevis d'Athouguia (1917-2006) with the collaboration of the landscape designers Ribeiro Barreto (1924-2013) and Gonçalo Ribeiro Telles (1922-). The construction brought together an international interdisciplinary team of specialists. The most up-to-date techniques were adopted in its construction, including reinforced and pre-stressed concrete. Some figures illustrate the volume of these buildings: $150,000 \mathrm{~m}^{3}$ of excavation, $45,000 \mathrm{~m}^{3}$ of concrete, 3,200 tons of steel, 100 $\mathrm{km}$ of power cables, 50,000 $\mathrm{m}$ of air conditioning pipes and 3,500 kW of installed electrical capacity. The impact that the complex has had, and the way in which it has manifested the effectiveness of its qualities, such as formal sobriety and restraint, have confirmed the close relationship between its design process and the construction site (Figure 7).

At the end of the 1990s, the Foundation began a programme of renovation and rehabilitation of its buildings and garden. The last phase concerned the area of the Congress Centre, which was subject to a partial intervention between 2005 and 2006. The intervention in the Main
Auditorium was the last stage of this programme. In fact, after 45 years of being open to the public, the Main Auditorium was revealing signs of deterioration: both in terms of wear of the cladding materials and technical installations, and its level of compliance with current European safety standards, and in terms of current comfort parameters and technology, namely adequate lighting and ventilation. Lastly, the intervention provided an opportunity to respond, through the use of $21^{\text {st }}$-century technologies, to the ambitious goals of the initial programme, which had not been satisfactorily met in terms of the versatility of planned functions articulated with excellent acoustics.

The Main Auditorium is a work of unparalleled architectural value, marked at the same time by a beauty of character and an intimate atmosphere. Its structural logic, constructive rigor and programmatic synthesis contribute to a clear reading of the space and to the harmony of the environment. It was important to maintain the unique atmosphere of the Main Auditorium with its combination of comfort and solemnity that lend it the prestige of being considered one of the most beautiful concert halls in the world.

To preserve the essence of this great architectural structure, all the elements of the room, from the wood of the walls, to the carpet, and the padding of the chairs, were restored to respect the character of the space, maintaining the rules of the architectural language and the logic of materials of the original project.

The coordination between materials and basic design concepts, specifically the respect for the continuous character of the space, determined that any intervention should respect the matrix of the original design of the auditorium. 


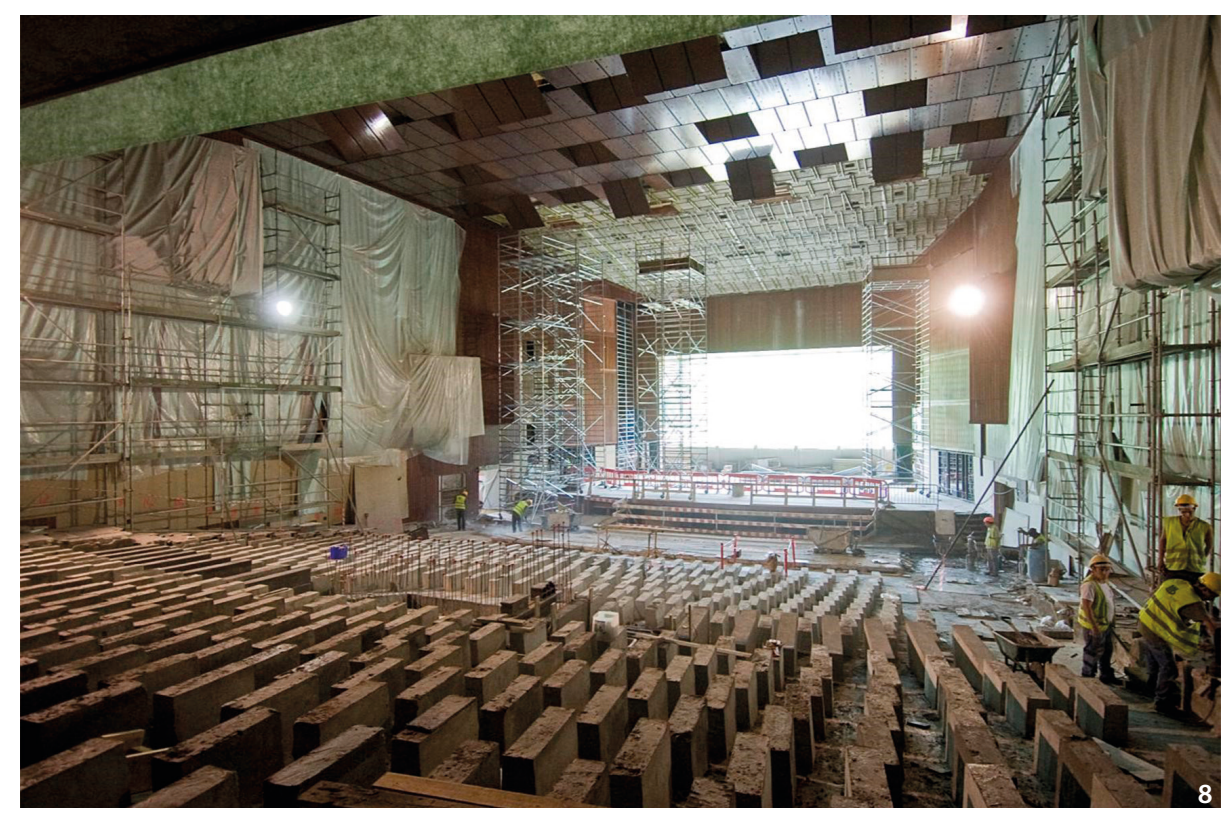

Figure 8 Alberto Pessoa, Pedro Cid, Rui Athouguia, Calouste Gulbenkian Foundation, Lisbon, Portugal, 1969. Renovation of the Auditorium, 2013 (Source: Márcia Lessa).

Its classification as a national monument, in 2010, should also be noted, as it had a decisive impact on the course of the restoration and allowed impositions of the current legal and regulatory framework to be circumvented which could have been disastrous if blindly enforced. The issue of restrictions governing interventions on the built heritage and the tolerance for changing these spaces is on the contemporary agenda. It is believed that the restoration and renovation of the Main Auditorium constitutes a model intervention in this context (Grignolo 2013).

The major purpose of the restoration of the Main Auditorium consisted in the adaptation of safety conditions and technical aspects, as well as in the improvement of the performative conditions of the scene in order to expand the audience experience to include current entertainment requirements such as multimedia or opera. Along with these improvements, the spaces were refurbished and the conditions for receiving the public improved. Thus, the work carried out was essentially of a technical and technological character, resulting in the complete replacement of stage and audio-visual equipment and infrastructure networks, including the air conditioning system. At the same time, improvements were introduced to enhance the acoustics of the room, the fire safety conditions were upgraded, and accessibility and comfort parameters were improved for the audience, users and artists (Figure 8).

The work covered $7,800 \mathrm{~m}^{2}$ and included, in addition to the Main Auditorium itself, the stage, the auditorium and balcony, the over-stage and sub-stage, technical and administrative support areas, the rehearsal rooms for the orchestra and choir, as well as the technical support areas, which now have infrastructures adapted to current regulations on safety, quality and operability.

Considered an intervention of great complexity, both for its technical requirements and by current safety standards, the work involved a significant investment, and demanded rigorous planning so that it could be completed in a reduced time-period with the inconvenience of interruptions to its activity being minimised.

The excellence of the Main Auditorium, the precise design of the plan and elevations, the harmonious asymmetrical distribution of the lateral volumes, the form resulting from a scrupulous structuring accompanied by a careful selection of materials, meant that the work was fundamentally one of restoration, mainly focused on technical and infrastructure improvements. As Teresa Nunes da Ponte stated: 'The intervention is being done with absolute respect for the rules of the original design and the principles of the existing construction. This is a restoration intervention, and a very conservative one from the formal point of view, only addressing essential changes. However, when design changes are imperative, we always opt for contemporary solutions that acknowledge the intervention, although inspired and governed by the rules of the initial project.' (Nunes 2013)

The technical component represented a substantial part of the investment. As mentioned above, technological evolution, and regulations that have been produced with respect to safety, energy efficiency and indoor air quality, among other things, led to the total replacement of its technical equipment and infrastructure. While respecting the architecture of space, it was possible to design the 


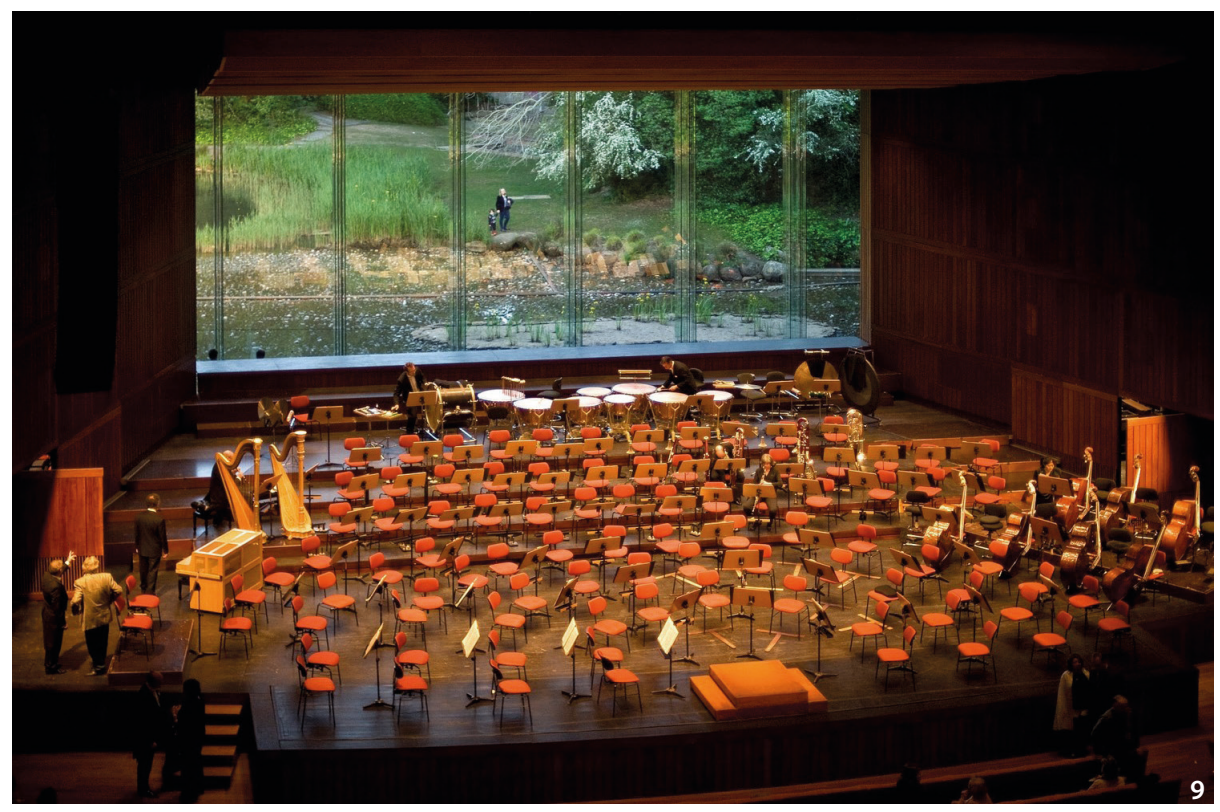

Figure 9 Alberto Pessoa, Pedro Cid, Rui Athouguia, Calouste Gulbenkian Foundation, Lisbon, Portugal, 1969. Auditorium after the renovation (Source: Márcia Lessa).

technological component in the most diverse specialties, taking into account the specific needs of the Auditorium and other factors, such as versatility, reliability and simplicity of operation (Tomás 2012). In addition to environmental awareness in the selection of solutions, which was decisive in the choice of more energy-efficient equipment, technology was used to provide comfortable conditions for the entire audience, regardless of mobility, hearing or visual limitations. In addition, the restored and renovated Auditorium, although benefiting from more recent developments, remained fully compatible with the systems already installed in the other auditoriums and congress rooms, so that it can be integrated into larger events.

Its classification as a National Monument allowed an exemplary conservation intervention to be undertaken in compliance with European Union rules on energy efficiency, and security, fire alarm and detection systems and anti-seismic prevention. On the one hand it was necessary to preserve the memory of this representative and architecturally unique building, and on the other, it was necessary to meet the standards for comfort and contemporary use. The successful resolution of this confirms the building's capacity to withstand time and use, and upholds the excellence of its original structural characteristics, construction and materials (Figure 9).

The intervention project was carried out in a constant dialogue with the existing, based on the memory and documentation of its history, and the selection of its essential values, methods and criteria for action (Tostões 2012). The structural characteristics, material and constructional qualities of the building, allied to design flexibility, helped enable the maintenance and adaptation required by its use and the passage of time, without harming its undeniable architectural quality. In this sense, it is possible to undertake interventions such as restorations, while maintaining the values of the initial design and meeting the regulatory requirements and standards of habitability of this type of facility. While most interventions conducted meet the technical requirements to comply with European codes, others address current requirements of comfort such as the relationship between space and lighting, new materials, health and environment, while honouring the nobility of the original design.

\section{Beyond a Design Action: Cultural Assessment and Education Strategy}

If one may admit that civilization is going through a digital revolution, it means that a new era characterised by technology, which increases the speed and breadth of knowledge turnover within the economy and society, is coming. The rapid shift from traditional industry for an economy based on information technology continues permanently to change over time as new methods of interaction with other humans and devices enter the domain of research, development and market promotion (Castells 1999). This digital revolution means the shift from mechanical and analogue electronic to digital technology which began anywhere from the late 1950s to the late 1970s with the adoption and proliferation of digital computers and record until to the present day. It might be not by chance that it coincides with the moment when the 
discussion about heritage, namely the built heritage, gains a new breath. After the Venice Chart in 1964, a new facing page introduced a fresh insight on contemporary intervention in the built heritage as well as the awareness concerning urban landscape, beyond the value of the single architectural pieces.

Just as Ruskin's (1851-1853) defense of the past being at risk of vanishing at the height of the industrial revolution in 1851, today the digital wave has triggered reactions that call for the need of not losing the analog world, and to that extent, throwing the issue of reproducibility in the wake of Walter Benjamin (1935). And by this way, summoning to the present world the relevance of the memory and the values of authenticity, originality and legitimacy. The sociologist Manuel Castells describes the shift from an industrial to an informational society considering that the information age has affected the workforce in several ways. This network society is structured around networks instead of individual actors and works through a constant flow of information through technology (Castells 1999). This switch-over had the greatest impact on patrimonial policies since documentation and research are at the first step for conservation and restoration policies. This is to say that the research on built heritage is itself encompassed in the global culture. As Castells emphasises, within the scope of the interrelationship of social, economic and political features of society, the 'network' is the defining feature that marks our current epoch. In the digital age the return to the most perennial sources and the material structures is the natural reaction. But in fact, this reaction occurs in an increasingly globalised world where information, namely techniques and concepts on intervention in heritage, has proliferated exponentially.

One knows that buildings are rooted in its materiality and that the material history represents an important field of investigation. The monographic study is a necessary step in order to understand not only the articulation of the space and its use, as well the different industrialised constructive systems experienced throughout the $20^{\text {th }}$ century. The combination of the material criteria with the intangible or socio-cultural issues, strengthens the richness of the analysis that extends to the transversality of material history, but also of the social, political and cultural history (Graf 2014).

All the four presented buildings achieved a status of cultural significance as outstanding pieces of architecture, its building integrity was maintained within its consistency in handling of space and materials. All the interventions analysed are exemplary of revealing dilemmas on authenticity, originality and legitimacy. As Laurajane Smith (2006) states, the realm of our built heritage is centred on the understanding of human experiences, rituals and social history that add meaningful narratives to physical fabric, structures and artefacts ${ }^{18}$.

The Tugendhat House is nowadays a living exhibition and a repository of memory not only for the citizens of the Czech Republic but also for the society at a large. The intervention in this unique built heritage offers a rare narrative of the ideology and politics of the Western world and the everyday life reconstructed. It reveals how was the domestic space before the Nazi invasion, the family exile, and the use transformations which occurred during the socialist period of collectivisation. The restoration process was about the respect by the domestic space memory, being this memory question intrinsically attached to the process by which the built heritage was produced and its endurance relationship with the socio-cultural change. The Crown Hall is also a testimony of exile, but not in the same way. It is the living lesson of how Ludwig Mies van der Rohe, a European architect, encountered the steel American craft culture that would change forever his way to understand and make architecture. Not only revealing the eternal benefits of the experience exchange, it reveals how architecture can be a powerful tool to shape culture. The NMWA restoration proofs how the collective awareness of a symbolic built heritage led to the practice of re-use and restoration, moved by the need to improve security standards. For Japanese culture, the building that Le Corbusier designed with Sakakura and Maekawa, is the shift mark of a triple new era. First it represents the opening of Nipponic culture to the Western world, second it is the successful affirmation of post-war reconstruction in the Ueno Park, and third, it is the first building where the seismic retrofit was applied in such a scale of success, in Japan. The Gulbenkian Foundation represents the generous gift of the Armenian millionaire to the public realm, the WWII and the way to survive through culture to a dark dictatorship system in Portugal. Finally, the reuse of these buildings reveals how ideology and politics take aim at architectural heritage as powerful tool to shape not just the landscape of cities, but the culture of its people and the way they practice everyday life. Its restoration, keeping the character of the former fabric, is the proof of a cultural and social commitment.

Following Hanna Arendt's approach which considers that 'the reality and reliability of the human world rests primarily on the fact that we are surrounded by things more permanent than the activity by which they were 
produced', the architectural fabric is perceived as memory, and to that extend is envisaged as built remaining structures (Arendt 1958).

Within the economic crisis that has hit the real estate market and created a greater availability of buildings, new opportunities emerged for the recovery and re-use of modern heritage. In many cases, new buildings are no longer economically viable and beyond purely economic arguments, the benefits of the adaptive re-use of Modern Movement buildings is now starting to be recognised for enhancing identity and sustainability ${ }^{19}$. To erect new buildings, when it involves abandoning older ones, is beginning to be seen as socially unacceptable. Local governments and national policies are waking up to this and beginning to develop measures and alleviate regulations that limit the alternative use of abandoned buildings, and provide legislation for temporary uses, such as affordable housing for young people, which is urgently needed.

The time has come to reflect these issues in the teaching of architecture and modify the study curriculum to encourage the involvement of students in the development of knowledge and experience directed to adaptive re-use, in connection with memory, contemporary society and the potentialities of the future. The need for a consensus to gather knowledge in the international context and the importance of an exchange of experiences leads to take seriously the challenge that reuse, including restoration and renovation of built heritage, presents to architecture, considering economy and quality of life, for a better future. The digital era, if connected to the use and preservation of our collective memory and the needed transformation of the present, can lead us for a future where the combination of different times and places will necessary involve us within emotion.

\section{Notes}

1. The buildings, sites and neighbourhoods of the Modern Movement, are now at greater risk than during any other period. At the end of the 1980s, many modern masterpieces had already been demolished or changed beyond recognition. This was mainly due to the fact that many were not considered to be elements of heritage, that their original functions had substantially changed or that their technological innovations have not always survived long-term stresses. DOCOMOMO was founded in 1988 with the main goals brought together in the Eindhoven Statement which was issued at the conclusion of the founding conference in 1990: bring the significance of the Modern Movement to the attention of the public, the authorities, the professionals and the educational community concerned with the built environment; identify and promote the recording of the works of the Modern Movement, including a register, drawings, photographs, archives and other documents; foster the development of appropriate techniques and methods of conservation and disseminate this knowledge throughout the professions; oppose destruction and disfigurement of significant works of the Modern Movement; Identify and attract funding for documentation and conservation; explore and develop the knowledge of the Modern Movement.

2. For a discussion of this issue with regards to a particular building, see Hubert-Jan Henket and Wessel de Jonge, "A restoration concept for Modern Movement architecture", in Paul Meurs and Marie-Thérèse van Thoor (eds.), Sanatorium Zonnestraal: The history and restoration of a modern monument, Rotterdam, NAi Publishers, 2010, p. 98-101.

3. Ana Tostões (ed.), Docomomo Journal, n. 44-Modern and Sustainable, Barcelona, Docomomo International, 2011.

4. See Ana Tostões, Ivo Hammer, Zara Ferreira, "The Rebirth of the Tugendhat House", Docomomo Journal, n. 56 - The Heritage of Mies, Lisboa, Docomomo International, p. 45-53, 2017; Mark Sexton, "Restoration of Crown Hall", in Ana Tostões, Jong Soung Kimm and Tae-woo Kim (ed.), Proceedings of the 13th Docomomo International Conference Seoul - Expansion \& Conflict, Seoul, Docomomo Korea, 2014; Mark Sexton, "Restoration of Crown Hall", Docomomo Journal, n. 56 - The Heritage of Mies, Lisboa, Docomomo International, 2017, p. 64-71.

5. Fritz Tugendhat, Die Form, 6. Jahr, Heft 11, 15. Nov. 1931, 438. '....whenever I let these rooms and all they contain take their effect, I am overcome by the feeling that this is beauty, this is truth. See Daniela Hammer-Tugendhat, Ivo Hammer and Wolf Tegethoff, Tugendhat House. Ludwig Mies van der Rohle, Basel, Birkhäuser Verlag, 2015, p. 161.

6. The house was poorly maintained for decades, through a dramatic life: shortly after the Tugendhat family's flight from Czechoslovakia, it was confiscated by the Gestapo in 1939 while invading Czechoslovakia, and in 1942 became illegal property of the German Reich. Radical construction changes took place in the house during the Second World War. During the liberation of Czechoslovakia in 1945, the house was used for military purposes. From 1945 to 1950, a private dancing 
school was established there. In 1950, a rehabilitation centre for children with spinal defects was established until 1979. Between 1986 and 1994, with the goal of advertising the city, it hosted guests. The investor was the department of internal affairs of the National Committee of the City of Brno; the project was developed by the State Institute for Reconstruction of Historical Towns and Buildings in Brno and the design team consisted of Ing. arch. Jarmila Kutějová, Ing. Josef Janeček, Ing. arch. Adéla Jeřábková and was directed by Ing. arch. Kamil Fuchs, CSc., see Ivo Hammer, "Surface is Interface. History of the Tugendhat House 1938-1997. Criteria for the Preservation", in Daniela HammerTugendhat et al, 149-154.

7. Conducted by the HAWK (University of Applied Sciences and Arts, Hildesheim, Germany), under the guidance of the conservator/restorer Ivo Hammer, between 2003 and 2010.

8. We use that double term 'conservation-restoration' according to the decision of the Copenhagen conference of ICOM-CC (International Council of MuseumsCommittee for Conservation) in 1984 to keep clear the specific professional image of 'conservators-restorers' and the difference to the more general use of the term 'conservation' e.g. 'architecture conservation' which includes the work of architects also. See Ivo Hammer, "Materiality. History of the Tugendhat House 19972012. Conservation-science Study and Restoration", in Daniela Hammer-Tugendhat et al., 248.

9. For this, an association was formed combining three architectural offices from Brno: Omnia projekt, Archteam and RAW. However, the proposals originating from the conservation-science study had not been fully integrated in that project by the architects, justified by the argument that the architects would not be able to take responsibility for the conservation methods applied and this information was not necessary for obtaining a building permit. See Ivo Hammer, 178.

10. THICOM - acronym of Tugendhat House International Expert Commission. Members: Daniela Hammer-Tugendhat (Vienna), honorary chairperson; Ivo Hammer (Vienna), chairman; Wessel de Jonge (Rotterdam), deputy chairman; Iveta Černá (Brno), secretary; Alex Dill (Karlsruhe), Ana Tostões (Lisbon), Arthur Rüegg (Zurich), Helmut Reichwald (Stuttgart), Ruggero Tropeano (Zurich), Thomas Danzl (Dresden), Vladimír Šlapeta (Brno), Karel Ksandr (Prague), Petr Kroupa (Brno), Milos Solař (Prague), Josef Štulc (Prague), Martin Zednícek (Brno).
11. Grete Tugendhat, lecture held in the Brno House of Arts in the Czech language on 17 January 1969, in Daniela Hammer-Tugendhat et al., 20.

12. See Yoshiyuki Yamana, Kyo Fukuda, "National Museum of Western Art as Important Cultural Property of Japan: Its Evolution and Historical Value", Docomomo Journal, n. 53 - LC 50 Years After, Lisboa, Docomomo International, 2016.

13. The Museum was constructed in order to house and display the Matsukata Collection, after its repatriation to Japan as a gift of the French government.

14. Detailed construction plans and project management were undertaken by Kunio Mayekawa, Junzo Sakakura, and Takamasa Yoshizaka, Japanese architects who had worked in Le Corbusier's Atelier in Rue de Sevres 35.

15. Amongst various prototypes of that nature, the model Le Corbusier conceived for museums was the Museum of Unlimited Expansion (MUE). Starting with the conception of the World Museum as part of the 1929 Mundaneum project, Le Corbusier continued to develop and refine that concept.

16. Akiko Mabuchi, Introduction for 'Preservation and Utilisation Plan for the Main Building of the National Museum of Western Art (Important Cultural Property/ Building) and the Grounds of the National Museum of Western Art' (Registered Monument/Place of Scenic Beauty), September 2013.

17. Ana Tostões, Restauro e Renovação do Grande Auditório, Lisboa, FCG, 2015.

18. See also Mohamed Gamal Abdelmonem, "Architectural and urban heritage in the digital age: dilemmas of authenticity, originality and reproduction", International Journal of Architectural Research, volume 11, Issue 3, November 2017.

19. In 2014, at the $13^{\text {th }}$ International DOCOMOMO Conference that took place in Seoul, South Korea, DOCOMOMO updated its statement. The Eindhoven-Seoul Statement introduced a new aim-'Promote the conservation and (re)use of buildings and sites of the Modern Movement'-and the word 'reuse' was introduced in most of the challenges to reach and develop work on. DOCOMOMO values the innovative character of the Modern Movement according to its social, technical and aesthetical dimensions considering a long durée process and stating that the mission is not only to exchange knowhow and ideas on Modern Movement buildings, sites and neighbourhoods. The great goal is to formulate new ideas for the future of built environment based on past experiences of the Modern Movement. 


\section{References}

Abdelmonem, Mohamed Gamal. 2017. "Architectural and Urban Heritage in the Digital Age: Dilemmas of Authenticity, Originality and Reproduction." International Journal of Architectural Research 11 (3): 5-15.

Arendt, Hannah. 1958. The Human Condition. 2nd ed. Chicago: University of Chicago Press.

Banham, Reyner. 1960. Theory and Design in the First Machine Age. London: The Architectural Press.

Benjamin Walter. 1935. "The Work of Art in the Age of Mechanical Reproduction." In Illuminations. Walter Benjamin. Essays and Reflections, edited by Hannah Arendt, 1968. New York: Random House.

Castells Manuel. 1999. The Information Age, Volumes 1-3: Economy, Society and Culture. Oxford: Wiley-Blackwell.

Castells, Manuel. 2009. Communication Power. Oxford: Oxford University Press.

Cesare, Brandi. 2005. Theory of Restoration. Florence: Nardini Editore.

Damásio, António. 2003. Looking for Spinoza: Joy, Sorrow and the Feeling Brain. London: William Heinemann.

Graf, Franz, and Giulia Marino. 2011. "Modern and Green: Heritage, Energy, Economy” Docomomo Journal 44.

Graf, Franz. 2012. "Material History and Conservation of Contemporary Building Fabric.” In Nuts \& Bolts of Construction History, Culture, Technology and Society Vol. I, edited by Robert Carvais, André Guillerme, Valérie Nègre, Joel Sakarovitvh, 135-142. Paris: Picard.

Graf, Franz. 2014. Histoire matérielle du bâti et projet de sauvegarde. Devenir de l'architecture moderne et contemporaine [Material History of the Building and Project of Safeguard: Become a Modern and Contemporary Architecture]. Lausanne: Presses Polytechniques Universitaires Romandes.

Grignolo, Roberta, ed. 2013. Diritto e salvaguardia dellarchitettura del XX secolo [Law and the Preservation of 20th Century Architecture]. Mendrisio: Mendrisio Academy Press-Silvana Editoriale, MendrisioCinisello Balsamo

Gropius, Walter. 1955. Scope of Total Architecture. New York: Harper and Brothers.

Hammer, Ivo. 2014. "Surface is Interface: History of the Tugendhat House 1938-1997. Criteria for the Preservation." In Haus Tugendhat. Ludwig Mies van der Rohe, edited by Daniela Hammer-Tugendhat, Ivo Hammer, and Wolf Tegethoff, 149-154. Basel: Birkhäuser.

Hammer, Ivo. 2014. "Materiality. History of the Tugendhat
House 1997-2012. Conservation-science Study and Restoration.” In Haus Tugendhat. Ludwig Mies van der Rohe, edited by Daniela Hammer-Tugendhat, Ivo Hammer, and Wolf Tegethoff, 162-223. Basel: Birkhäuser.

Harboe, Gunny. 2000. S.R. Crown Hall Historic Structure Report. Chicago: McClier Preservation Group.

Harrington, Kevin. 1993. “S.R. Crown Hall.” In AIA guide to Chicago, edited by Alice Sinkevitch and Laurie McGovern Petersen, 388-389. San Diego: Harcourt Brace \& Co.

Henket, Hubert-Jan, and Wessel de Jonge. 2010. "A Restoration Concept for Modern Movement Architecture." In Sanatorium Zonnestraal: The History and Restoration of a Modern Monument, edited by Paul Meurs and Marie-Thérèse van Thoor, 98-101. Rotterdam: NAi Publishers.

Nicholson, Ben. 2018. "S.R. Crown Hall." Accessed June 15 2018. http://miessociety.org/mies/projects/s-rcrown-hall.

Nunes, Teresa. 2013. "Descriptive report of the project." In Restauro e Renovação do Grande Auditório, edited by Ana Tostões. Lisboa: FCG.

Okada, Tsuneo. 2009. "Seismic Retrofitting for The Main Building of the National Museum of Western Art." In Le Corbusier \& the National Museum of Western Art. Tokyo: Open Museum/The Western Art Foundation.

Prudon, Theodore. 2008. Preservation of Modern Architecture. New York: John Wiley \& Sons.

Prudon, Theodore. 2010. “The 'Modern' Challenge to Preservation.” Forum Journal 24 (4): 9-14.

Reichlin, Bruno. 2001. "Quelle histoire pour la sauveguarde du patrimoine architectural moderne et contemporain?" [What History for the Safeguarding of the Modern and Contemporary Architectural Heritage?] Patrimoine et Architecture 10-11: 50-57.

Riegl, Aloïs. 1982. “The Modern Cult of Monuments: Its Character and Its Origin.” Oppositions 25: 21-51.

Ruskin, John. 1851-1853. The Stones of Venice. 3 vols., London: Smith, Elder \& Co..

Ruskin, John. 1860. The Seven Lamps of Architecture. London: Smith, Elder.

Sexton, Mark. 2014. "Restoration of Crown Hall." In Proceedings of the 13th Docomomo International Conference Seoul - Expansion \& Conflict, edited by Ana Tostões, Jong Soung Kimm and Tae-woo Kim. Seoul: Docomomo Korea.

Sexton, Mark. 2017. "Restoration of Crown Hall.” Docomomo Journal 56: 64-71. 
Smith, Laurajane. 2006. Uses of Heritage. Oxon: Routledge. Stein, Carl. 2010. Greening Modernism: Preservation, Sustainability, and the Modern Movement. New York: W. W. Norton \& Co.

Tomás, Osório. 2012. "Relatório." In Restauro e Renovação do Grande Auditório, edited by Ana Tostões. Lisboa: FCG.

Tomlow, Jos, and Ola Wedebrunn, eds. 2006. Docomomo Preservation Technology Dossier 9: Climate and Building Physics in the Modern Movement. Paris: Docomomo International.

Tostões, Ana and Kecheng Liu, eds. 2014. Docomomo International 1988-2012: Key Papers in Modern Architectural Heritage Conservation. Beijing: China Architectural and Building Press.

Tostões, Ana and Zara Ferreira, eds. 2016. Adaptive Reuse: The Modern Movement towards the Future. Lisboa: Docomomo International/Casa da Arquitectura.

Tostões, Ana, and Aurora Carapinha. 2016. "The Creation of an Urban Landscape." In Adaptive Reuse: The Modern Movement towards the Future, edited by Ana Tostões, and Zara Ferreira. Lisboa: Docomomo International/Casa da Arquitectura.

Tostões, Ana, Ivo Hammer, and Zara Ferreira. 2017. "The Re-birth of the Tugendhat House." Docomomo Journal 56: 45-53.

Tostões, Ana, ed. 2011. Docomomo Journal, n. 44 Modern and Sustainable, Barcelona, Docomomo International, 2011.

Tostões, Ana. 2012. The Buildings, Calouste Gulbenkian Foundation. Lisboa: FCG.

Tostões, Ana. 2015a. Restauro e Renovação do Grande Auditório. Lisboa: FCG.

Tostões, Ana. 2015b. “Towards a New Monumentality: The Creation of an Urban Cultural Landscape." Journal of Architectural and Town-Planning Theory 49 (3-4): 240-257.

Tostões, Ana. 2015c "Learning from an Outstanding Process. The Gulbenkian Foundation Buildings (1959-1969)." In Proceedings of the Fifth International Congress on Construction History, edited by Bowen, B., Friedman, D., Leslie, T., and Oschendorf, J. Chicago: Construction History Society of America.

UNESCO. 2018. "Tugendhat Villa in Brnohttp." UNESCO World Heritage Centre. June 15 2018. http://whc. unesco.org/en/list/1052

Yamana, Yoshiyuki, and Kyo Fukuda. 2016. "National Museum of Western Art as Important Cultural Property of Japan: its Evolution and Historical Value." Docomomo Journal 53. 